\title{
PENGARUH SISTEM MANAJEMEN KESELAMATAN DAN KESEHATAN KERJA (SMK3) DAN LINGKUNGAN KERJA TERHADAP PRODUKTIVITAS KERJA KARYAWAN PADA PT. POST ENERGY INDONESIA
}

\author{
Dedi Mulyadi \\ Fakultas Ekonomi dan Bisnis Universitas Buana Perjuangan Karawang \\ Email: dedi.mulyadi@ubpkarawang.ac.id
}

\begin{abstract}
Abstrak
Penelitian ini bertujuan untuk mengetahui pengaruh sistem manajemen keselamatan dan kesehatan kerja (SMK3) dan lingkungan kerja terhadap produktivitas kerja karyawan. Penelitian ini menggunakan metode kuantitatif dengan pengumpulan data melalui teknik observasi, kuesioner, dan wawancara. Teknik analisis data penelitian ini menggunakan analisis jalur (path analysis). Hasil penelitian ini membuktikan bahwa terdapat hubungan atau korelasi antara sistem manajemen keselamatan dan kesehatan kerja $\left(\mathrm{X}_{1}\right)$ dengan lingkungan kerja $\left(\mathrm{X}_{2}\right)$. Selanjutnya, terdapat pengaruh parsial sistem manajemen keselamatan dan kesehatan kerja dan lingkungan kerja terhadap produktivitas kerja karyawan. Secara simultan, terdapat pengaruh yang signifikan antara sistem manajemen keselamatan dan kesehatan kerja dan lingkungan kerja terhadap produktivitas kerja karyawan.
\end{abstract}

Kata Kunci: Sistem Manajemen Keselamatan Kesehatan Kerja (SMK3), Lingkungan Kerja, Produktivitas Kerja.

\begin{abstract}
This study aims to determine the effect of occupational safety and health management systems (SMK3) and the work environment on employee work productivity. This study uses quantitative methods with data collection through observation, questionnaires, and interviews. The data analysis technique of this research is using path analysis. The results of this study prove that there is a relationship or correlation between the occupational safety and health management system (X1) and the work environment (X2). Furthermore, there is a partial influence of the occupational safety and health management system and the work environment on employee work productivity. Simultaneously, there is a significant influence between the occupational safety and health management system and the work environment on employee work productivity.
\end{abstract}

Keywords: Safety Management System Occupational Health (SMK3), Work Environment, Work Productivity.

\section{A. PENDAHULUAN}

Menurut Mangkunegara (2013), Keselamatan dan Kesehatan Kerja adalah suatu pemikiran dan upaya untuk menjamin keutuhan dan kesempurnaan baik jasmaniah maupun rohaniah tenaga kerja pada khususnya, dan manusia pada umumnya, hasil karya dan budaya untuk menuju masyarakat adil dan makmur. Karyawan harus mempunyai kondisi fisik yang 
sehat dan lingkungan yang mendukung agar terhindar dari kecelakaan kerja (Ramli, 2010; Ridley, 2006). Kemudian menurut Bangun (2012), Sistem Manajemen Keselamatan dan Kesehatan Kerja (SMK3) adalah bagian dari sistem manajemen keseluruhan yang meliputi struktur organisasi, perencanaan, tanggung jawab, pelaksanaan, prosedur, proses dan sumber daya yang dibutuhkan bagi pengembangan, penerapan, pencapaian, pengkajian, dan pemeliharaan kebijakan keselamatan dan kesehatan kerja dalam rangka pengendalian risiko yang berkaitan dengan kegiatan guna tercapainya tempat kerja yang aman, efektif, dan produktif (Kurnia, 2005).

Salah satu yang dapat memberikan produktifitas kerja adalah lingkungan yang nyaman (Sutanto \& Suwondo, 2019). Lingkungan adalah segala sesuatu yang berada diluar sistem. Lingkungan dapat berpengaruh terhadap operasi sistem sehingga dapat merugikan atau menguntungkan sistem itu sendiri (Rinarti \& Renyowijoyo, 2007). Lingkungan yang merugikan tentu saja harus ditahan dan dikendalikan supaya tidak mengganggu kelangsungan operasi sistem. Sementara itu, lingkungan yang menguntungkan tetap harus terus dijaga karena akan memacu terhadap kelangsungan hidup sistem (Ramli, 2013).

Adapun produktivitas kerja karyawan adalah ukuran berapa banyak nilai tambah yang diberikan pekerja secara individual terhadap barang atau jasa yang dihasilkan organisasi (Kaswan, 2012). Sedangkan Menurut Hasibuan (2009), Kinerja adalah suatu hasil kerja yang dicapai seseorang dalam melaksanakan tugas-tugas yang dibebankan kepadanya yang didasarkan atas kecakapan, pengalaman, dan kesungguhan serta waktu (Ike, 2008; Sakban dkk, 2019).

PT. Post Energy Indonesia mempunyai sistem manajemen mutu keselamatan dan kesehatan kerja (k3) dan lingkungan kerja yang baik, pengelolaan operasinya sesuai dengan ketentuan dan peraturan perundang-undangan dengan tujuan perbaikan atau pengembangan pengelolaan operasi secara menyeluruh dan terpadu. Namun dalam pelaksanaan dan kenyataannya masih belum sesuai dengan yang ditujukan diatas, diantaranya dapat dilihat pada gambar dan tabel dibawah ini : 


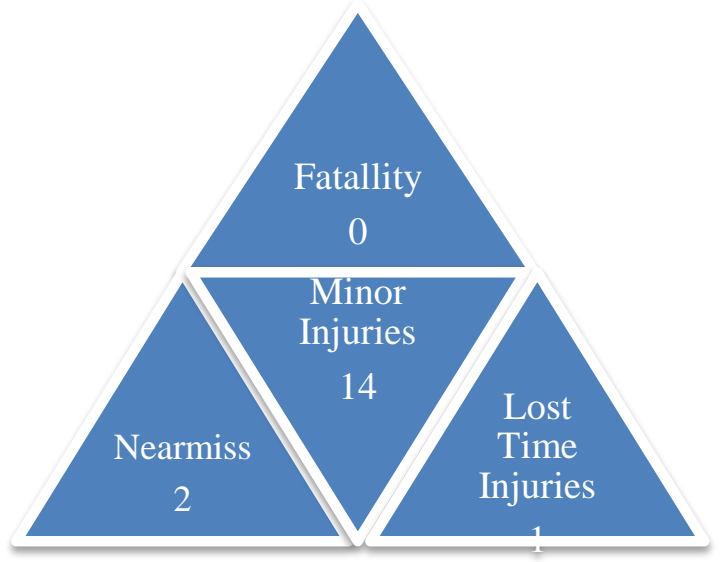

Sumber : PT. Post Energy Indonesia

\section{Gambar 1 Piramida Kecelakaan Kerja PT. Post Energy Indonesia Periode Oktober 2010 - April 2011}

Tabel 1 Safety Performance Matrics Periode Oktober 2010 - April 2011

\begin{tabular}{|c|c|c|c|c|c|c|c|c|}
\hline $\begin{array}{l}\text { Performance } \\
\text { Indicator }\end{array}$ & Total & Okt & Nov & Des & Jan & Feb & Maret & April \\
\hline Total Employee & & 96 & 96 & 110 & 112 & 140 & 146 & 146 \\
\hline No of Fatalities & 0 & 0 & 0 & 0 & 0 & 0 & 0 & 0 \\
\hline Nearmiss & 2 & 1 & 0 & 0 & 0 & 1 & 0 & 0 \\
\hline First Aid & 6 & 2 & 1 & 0 & 2 & 0 & 0 & 1 \\
\hline $\begin{array}{l}\text { Medical } \\
\text { Treatment Case }\end{array}$ & 7 & 0 & 1 & 1 & 1 & 3 & 0 & 1 \\
\hline Total Incident & 14 & 3 & 2 & 1 & 3 & 4 & 0 & 1 \\
\hline Total Accident & 1 & 0 & 0 & 0 & 0 & 0 & 0 & 1 \\
\hline $\begin{array}{ll}\text { Lost } & \text { Time } \\
\text { Injury } & \end{array}$ & 1 & 0 & 0 & 0 & 0 & 0 & 0 & 1 \\
\hline $\begin{array}{ll}\text { Total } & \text { Work } \\
\text { Hour } & \\
\end{array}$ & 134.400 & 18.432 & 18.432 & 21.120 & 21.504 & 26.880 & 28.032 & 0 \\
\hline $\begin{array}{l}\text { Mobile Vehicle } \\
\text { Crashes Rate }\end{array}$ & 0 & 0 & 0 & 0 & 0 & 0 & 0 & 0 \\
\hline $\begin{array}{l}\text { Environment } \\
\text { Damage }\end{array}$ & 0 & 0 & 0 & 0 & 0 & 0 & 0 & 0 \\
\hline $\begin{array}{l}\text { Frequency Rate } \\
\text { (Kekerapan) }\end{array}$ & $<15$ & 0 & 0 & 0 & 0 & 0 & 0 & 7,13 \\
\hline $\begin{array}{l}\text { Saverity Rate } \\
\text { (Keparahan)) }\end{array}$ & $<10$ & 0 & 0 & 0 & 0 & 0 & 0 & 21,4 \\
\hline \multicolumn{5}{|c|}{ Tingkat Keparahan (Saverity Rate) } & \multicolumn{3}{|c|}{ Jumlah Hari Hilang } & 134.400 \\
\hline \multicolumn{5}{|c|}{ Jumlah Hari Hilang x 200.000 } & \multicolumn{3}{|c|}{$\begin{array}{c}\text { Jumlah Jam Kerja Yang } \\
\text { Hilang }\end{array}$} & 28.032 \\
\hline
\end{tabular}

Sumber : PT. Post Energy Indonesia

Dari gambar dan tabel diatas dapat disimpulkan, bahwa masih sering terjadi tingkat kecelakaan kerja dan berupa waktu atau jam kerja yang terbuang akibat kecelakaan kerja 
pada PT. Post Energy Indonesia pada periode oktober 2010 sampai dengan april 2011, sehingga memacu kepada menurunnya produktivitas kerja karyawan.

Pada tahun 2012, rata-rata produksi minyak dan gas bumi mencapai sebesar 2,31 juta barel minyak ekuivalen per hari. Berdasarkan data produksi, periode 2007 sampai 2010 terjadi kenaikan produksi minyak dan gas bumi, namun pada tahun 2012 mengalami penurunan produksi diantaranya dapat dilihat pada gambar dibawah ini :

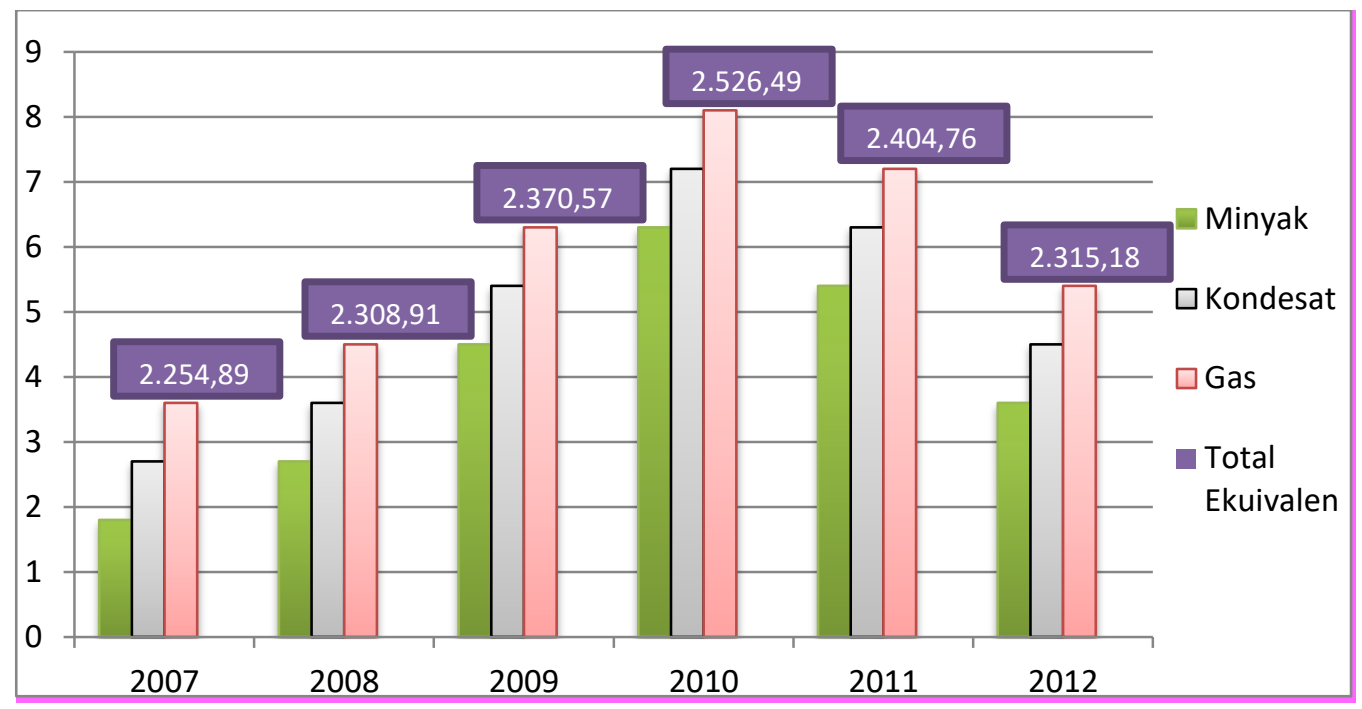

Gambar 2 Produksi Minyak dan Gas Bumi

Terciptanya produktivitas kerja terhadap profesinya itu tergantung bagaimana perusahaan tersebut dapat menciptakan lingkungan kerja yang baik dan memperhatikan tingkat keselamatan dan kesehatan kerjanya, agar semua para karyawan merasa aman dan nyaman pada saat bekerja (Aspiyah \& Martono, 2016).

Dengan demikian sistem manajemen keselamatan dan kesehatan kerja (SMK3) dan lingkungan kerja dapat berpengaruh besar terhadap produktivitas kerja karyawan sehingga visi dan misi yang telah di buat akan tercapai secara optimal (Lestari \& Trisyulianti, 2009).

Penulis melakukan observasi pada PT. Post Energy Indonesia karena menemukan berbagai masalah yang ada, terutama mengenai Sistem Manajemen Keselamatan dan Kesehatan Kerja (SMK3), lingkungan kerja dan produktivitas kerja karyawan. Dengan berkembangnya PT. Post Energy Indonesia pasti akan banyak dan bertambahnya karyawan yang akan bekerja. Berdasarkan uraian dia atas, maka tujuan penelitian ini adalah untuk menguji pengaruh Sistem Manajemen Keselamatan dan Kesehatan Kerja (SMK3) dan lingkungan kerja terhadap produktivitas kerja karyawan pada PT. Post Energy Indonesia. 


\section{B. METODE}

Berdasarkan metode penelitiannya, desain penelitian ini adalah penelitian survey dimana peneliti terjun langsung ke lapangan untuk memperoleh data dengan menggunakan kuisioner. metode survey yaitu suatu metode yang digunakan untuk memperoleh fakta-fakta dari gejala-gejala yang ada dan mencari keterangan-keterangan secara faktual (Nazir, 1988). Berdasarkan tingkat eksplanasinya, metode penelitian ini bersifat deskriptif, Menurut Sugiyono (2012), penelitian deskriptif adalah penelitian yang dilakukan untuk mengetahui nilai variabel mandiri, baik satu variabel atau lebih (independent) tanpa membuat perbandingan atau menghubungkan dengan variabel yang lain. Sementara, berdasarkan rancangan jenis data dan analisisnya, penelitian ini termasuk analisis data kuantitatif. Menurut Sugiyono (2010), kuantitatif metode penelitian yang digunakan untuk penelitian populasi atau sampel tertentu, dan analisis data bersifat statistik dengan tujuan untuk menguji hipotesis yang telah ditetapkan.

Variabel yang digunakan dalampenelitianini ada 3, yaitu Sistem Manajemen Keselamatan dan Kesehatan Kerja (SMK3) $\left(\mathrm{X}_{1}\right)$, lingkungan kerja $\left(\mathrm{X}_{2}\right)$ dan produktivitas kerja (Y). Populasi dalam penelitian ini adalah seluruh karyawan PT Post Energy. Teknik penentuan sampel dilakukan dengan teknik cluster random sampling dimana yang menjadi unit sampling dalam kerangka sampling adalah rumpun-rumpun atau kelompok-kelompok (Soehartono, 2000). Pengumpulan data dilakukan melalui teknik observasi, kuesioner, dan wawancara, sedangkan dan analisis data yang digunakan analisis jalur (Path Analysis).

\section{HASIL DAN PEMBAHASAN}

\section{Besaran Hubungan Antara Variabel Bebas}

Dalam analisis jalur, keterkaitan antar variabel bebas yang mempunyai hubungan berarti, dapat dihitung besaran pengaruh langsung maupun pengaruh tidak langsung. Untuk pengaruh tidak langsung merupakan perkalian antara koefisien jalur dengan koefisien korelasinya. Oleh karena itu terlebih dahulu dihitung masing-masing besaran koefisien korelasi di antara variabel bebas tersebut. Untuk lebih jelasnya hubungan antara kedua variabel bebas tersebut dapat dijelaskan pada tabel 2 di bawah ini: 
Tabel 2 Tabel Korelasi

Correlations

\begin{tabular}{|c|c|c|c|}
\hline & & $\begin{array}{l}\text { Sistem Manajemen } \\
\text { Keselamatan dan } \\
\text { Kesehatan Kerja } \\
\end{array}$ & $\begin{array}{c}\text { Lingkungan } \\
\text { Kerja }\end{array}$ \\
\hline $\begin{array}{l}\text { Sistem Manajemen } \\
\text { Keselamatan dan } \\
\text { Kesehatan Kerja }\end{array}$ & $\begin{array}{l}\text { Pearson Correlation } \\
\text { Sig. (2-tailed) } \\
\mathrm{N}\end{array}$ & $\begin{array}{r}1 \\
102 \\
\end{array}$ & $\begin{array}{r}, 503^{* *} \\
, 000 \\
102\end{array}$ \\
\hline Lingkungan Kerja & $\begin{array}{l}\text { Pearson Correlation } \\
\text { Sig. (2-tailed) } \\
\mathrm{N}\end{array}$ & $\begin{array}{r}, 503^{* *} \\
, 000 \\
102 \\
\end{array}$ & 102 \\
\hline
\end{tabular}

Berdasarkan tabel 4.101 di atas, nilai koefeisien korelasi antara variabel bebas yaitu Sistem Manajemen Keselamatan dan Kesehatan Kerja $\left(\mathrm{X}_{1}\right)$ dan Lingkungan Kerja $\left(\mathrm{X}_{2}\right)$ adalah 0,503. Korelasi tersebut dapat dijelaskan dengan gambar di bawah ini:

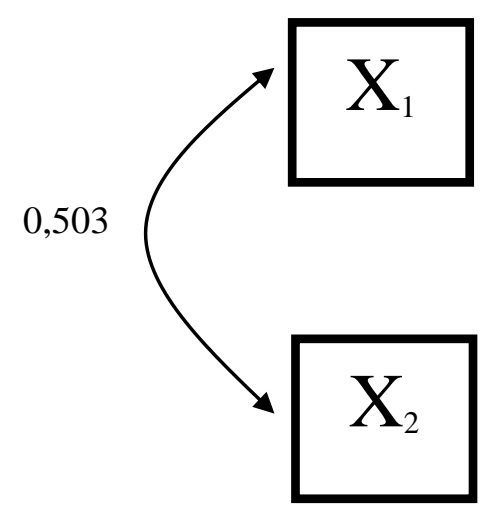

Gambar 3 Hubungan Antar Variabel Bebas $X_{1}$ dan $X_{2}$

Dari hasil analisis diperoleh besaran koefisien korelasi antara variabel bebas yaitu Sistem Manajemen Keselamatan dan Kesehatan Kerja $\left(\mathrm{X}_{1}\right)$ dan Lingkungan Kerja $\left(\mathrm{X}_{2}\right)$ dapat dinilai sebesar 0,503. Dengan demikian Sistem Manajemen Keselamatan dan Kesehatan Kerja $\left(X_{1}\right)$ dan Lingkungan Kerja $\left(X_{2}\right)$ memiliki tingkat hubungan yang kuat dan searah karena nilai positif.

\section{Analisis Jalur (Path Analysis)}

Berdasarkan hasil pengolahan data dengan menggunakan software SPSS 18, diperoleh koefisien jalur untuk setiap Sistem Manajemen Keselamatan dan Kesehatan Kerja $\left(\mathrm{X}_{1}\right)$ dan lingkungan kerja $\left(\mathrm{X}_{2}\right)$ terhadap produktivitas kerja karyawan $(\mathrm{Y})$. Hasil analisis tersebut dapat dilihat pada tabel di bawah ini: 


\section{Tabel 3 Tabel Koefisien}

\begin{tabular}{|c|c|c|c|c|c|}
\hline \multicolumn{6}{|c|}{ Coefficients $^{\mathrm{a}}$} \\
\hline \multirow[t]{2}{*}{ Model } & \multicolumn{2}{|c|}{$\begin{array}{c}\text { Unstandardized } \\
\text { Coefficients }\end{array}$} & \multirow{2}{*}{$\begin{array}{l}\text { Standardized } \\
\text { Coefficients } \\
\text { Beta }\end{array}$} & \multirow[b]{2}{*}{$\mathrm{T}$} & \multirow[b]{2}{*}{ Sig. } \\
\hline & $\mathrm{B}$ & Std. Error & & & \\
\hline $1 \quad$ (Constant) & 9,614 & 3,722 & & 2,583 & 011 \\
\hline Sistem Manajemen Keselamatan dan &, 550 &, 072 & ,597 & 7,595 & 000 \\
\hline Kesehatan Kerja & & & & & \\
\hline Lingkungan Kerja & ,227 & 079 & ,226 & 2,882 & 005 \\
\hline
\end{tabular}

a. Dependent Variable: Produktivitas Kerja Karyawan

Sumber : Hasil Pengolahan Data, 2019

Berdasarkan tabel 3 di atas diketahui bahwa koefisien jalur antara variabel Sistem Manajemen Keselamatan dan Kesehatan Kerja $\left(X_{1}\right)$ dan lingkungan kerja $\left(X_{2}\right)$ terhadap produktivitas kerja karyawan (Y). Nilai-nilai koefisien jalur tersebut masing-masing dijelaskan sebagai berikut:

1. Koefisien Jalur variabel Sistem Manajemen Keselamatan dan Kesehatan Kerja $\left(\mathrm{X}_{1}\right)$ terhadap variabel Produktivitas Kerja Karyawan (Y)

Berdasarkan tabel 4.102, koefeisien jalur untuk variabel Sistem Manajemen Keselamatan dan Kesehatan Kerja ( $\left.\mathrm{X}_{1}\right)$ terhadap variabel Produktivitas Kerja Karyawan (Y) adalah 0,597. Hal ini menunjukan bahwa pengaruh langsung Sistem Manajemen Keselamatan dan Kesehatan Kerja $\left(\mathrm{X}_{1}\right)$ terhadap variabel Produktivitas Kerja Karyawan (Y) adalah sebesar 0,597. Sehingga di peroleh persamaan $\mathbf{Y = 0 , 5 9 7} \mathbf{X}_{\mathbf{1}}$. Pengaruh langsung variabel $\mathrm{X} 1$ terhadap variabel Y dapat digambarkan seperti di bawah ini:

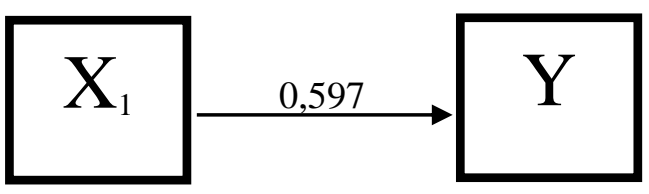

Gambar 4 Pengaruh Parsial Sistem Manajemen Keselamatan dan Kesehatan Kerja $\left(\mathrm{X}_{1}\right)$ terhadap Produktivitas Kerja Karyawan (Y)

2. Koefisien Jalur variablel Lingkungan Kerja (X2) terhadap variabel Produktivitas Kerja Karyawan (Y)

Berdasarkan tabel 3, koefisien jalur untuk variabel Lingkungan Kerja (X2) terhadap variabel Produktivitas Kerja Karyawan (Y) adalah sebesar 0,226. Hal ini menunjukan bahwa pengaruh langsung Lingkungan Kerja $\left(\mathrm{X}_{2}\right)$ terhadap variabel Produktivitas Kerja Karyawan (Y) adalah sebesar 0,226 sehingga diperoleh persamaan $\mathbf{Y = 0 , 2 2 6} \mathbf{X}_{2}$. Pengaruh langsung variabel X2 terhadap Y dapat digambarkan seperti dibawah ini: 


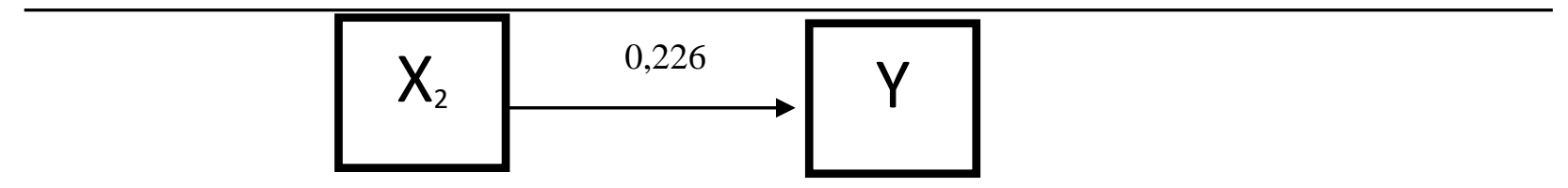

\section{Gambar 5 Pengaruh Parsial Lingkungan Kerja $\left(\mathbf{X}_{2}\right)$ terhadap variabel Produktivitas Kerja Karyawan (Y)}

Pengaruh langsung dan tidak langsung variabel Sistem Manajemen Keselamatan dan Kesehatan Kerja $\left(\mathrm{X}_{1}\right)$ dan Lingkungan Kerja $\left(\mathrm{X}_{2}\right)$ terhadap Produktivitas Kerja Karyawan $(\mathrm{Y})$ dapat digambarkan seperti di bawah ini:

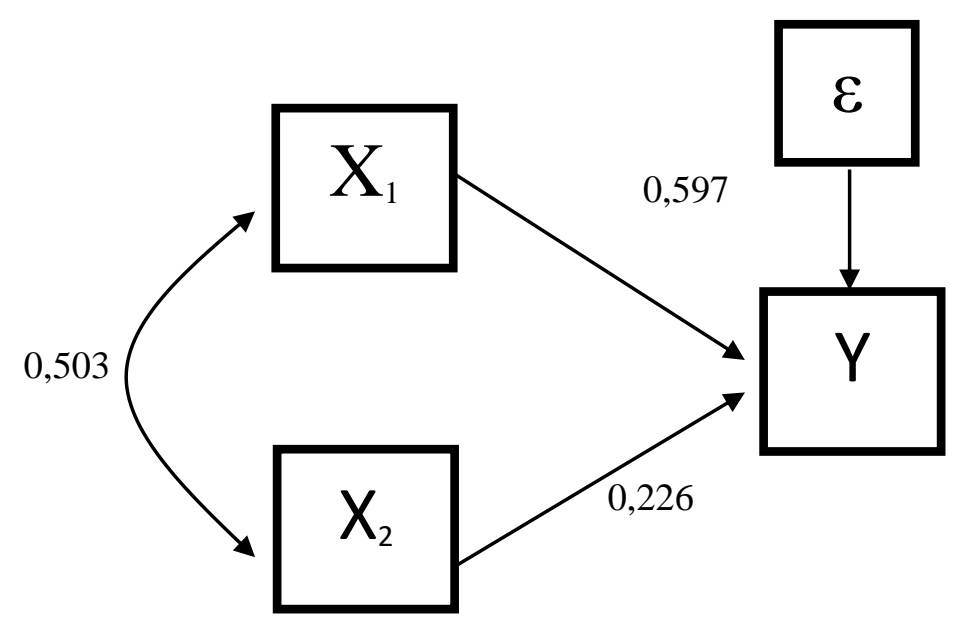

\section{Gambar 6 Pengaruh Langsung dan tidak langsung Variabel Sistem Manajemen Keselamatan dan Kesehatan Kerja $\left(X_{1}\right)$ dan Lingkungan Kerja $\left(X_{2}\right)$ terhadap Produktivitas Kerja Karyawan (Y)}

Berdasarkan gambar 6 di atas diketahui bahwa besaran koefisien jalur variabel Sistem Manajemen Keselamatan dan Kesehatan Kerja $\left(\mathrm{X}_{1}\right)$ 0,597 lebih tinggi dari variabel lingkungan kerja 0,226, artinya Sistem Manajemen Keselamatan dan Kesehatan Kerja $\left(\mathrm{X}_{1}\right)$ lebih berpengaruh terhadap produktivitas kerja karyawan (Y) dibandingkan dengan lingkungan kerja $\left(\mathrm{X}_{1}\right)$. Adapun persamaan jalurnya adalah sebagai berikut:

$$
Y=0,597 X_{1}+0,226 X_{2}
$$

Keterangan :

$\mathrm{X} 1=$ Sistem Manajemen Keselamatan dan Kesehatan Kerja

$\mathrm{X}_{2}=$ Lingkungan Kerja

$\mathrm{Y}=$ Produktivitas Kerja Karyawan

$\varepsilon=$ Variabel lain yang tidak diukur, tetapi mempengaruhi $Y$ 
Pengaruh langsung dan tidak langsung variabel Sistem Manajemen Keselamatan dan Kesehatan Kerja $\left(\mathrm{X}_{1}\right)$ terhadap produktivitas kerja karyawan $(\mathrm{Y})$ dapat dilihat pada tabel 4 berikut ini:

Tabel 4 Pengaruh Langsung dan Tidak Langsung Sistem Manajemen Keselamatan dan Kesehatan Kerja ( $\left.\mathrm{X}_{1}\right)$ terhadap variabel Produktivitas Kerja Karyawan (Y)

\begin{tabular}{|c|l|c|c|}
\hline Variabel & \multicolumn{1}{|c|}{$\begin{array}{c}\text { Interpretasi } \\
\text { Analisis Jalur }\end{array}$} & Perhitungan & $\begin{array}{c}\text { Besarnya } \\
\text { Pengaruh }\end{array}$ \\
\hline \multirow{2}{*}{$\begin{array}{c}\text { Sistem Manajemen } \\
\text { Keselamatan dan Kesehatan } \\
\text { Kerja }\end{array}$} & $\begin{array}{l}\text { Pengaruh } \\
\text { Langsung ke Y }\end{array}$ & $0,597^{2}$ & 0,356 \\
\cline { 2 - 4 } & $\begin{array}{l}\text { Pengaruh Tidak } \\
\text { Langsung X1 ke } \\
\text { Y }\end{array}$ & $\begin{array}{c}0,597 \times 0,226 \\
\text { x } 0,503\end{array}$ & 0,068 \\
\hline \multicolumn{2}{|c|}{ Jumlah } & 0,424 \\
\hline
\end{tabular}

Sumber: Hasil Pengolahan Data, 2019

Pada tabel 4 di atas menunjukan bahwa pengaruh variabel Sistem Manajemen Keselamatan dan Kesehatan Kerja $\left(\mathrm{X}_{1}\right)$ terhadap variabel produktivitas kerja karyawan $(\mathrm{Y})$ yaitu sebesar 0,424 atau sebesar 42,4\%, yang artinya pengaruh Sistem Manajemen Keselamatan dan Kesehatan Kerja $\left(\mathrm{X}_{1}\right)$ terhadap produktivitas kerja karyawan (Y) cukup tinggi.

Sedangkan pengaruh langsung dan tidak langsung lingkungan kerja $\left(\mathrm{X}_{2}\right)$ terhadap produktivitas kerja karyawan (Y) dapat dilihat pada tabel 5 berikut ini:

Tabel 5 Pengaruh Langsung dan Tidak Langsung Lingkungan Kerja $\left(\mathbf{X}_{2}\right)$ terhadap Produktivitas Kerja Karyawan (Y)

\begin{tabular}{|c|l|c|c|}
\hline Variabel & \multicolumn{1}{|c|}{$\begin{array}{c}\text { Interpretasi Analisis } \\
\text { Jalur }\end{array}$} & Perhitungan & $\begin{array}{c}\text { Besarnya } \\
\text { Pengaruh }\end{array}$ \\
\hline \multirow{3}{*}{ Lingkungan Kerja } & $\begin{array}{l}\text { Pengaruh Langsung ke } \\
\text { Y }\end{array}$ & $0,226^{2}$ & 0,051 \\
\cline { 2 - 4 } & $\begin{array}{l}\text { Pengaruh Tidak } \\
\text { Langsung X2 ke Y }\end{array}$ & $\begin{array}{c}0,226 \times 0,597 \\
\text { x 0,503 }\end{array}$ & 0,068 \\
\hline \multicolumn{1}{|c|}{ Jumlah } & 0,119 \\
\hline
\end{tabular}

Sumber: Hasil Pengolahan Data, 2019

Pada tabel 5 di atas menunjukan bahwa pengaruh variabel Lingkungan Kerja $\left(\mathrm{X}_{2}\right)$ terhadap produktivitas kerja karyawan (Y) yaitu sebesar 0,119 atau sebesar 1,19\%.yang artinya pengaruh Lingkungan Kerja $\left(\mathrm{X}_{1}\right)$ terhadap variabel produktivitas kerja karyawan $(\mathrm{Y})$ sangat rendah.

Pengaruh Sistem Manajemen Keselamatan dan Kesehatan Kerja $\left(\mathrm{X}_{1}\right)$ dan lingkungan kerja $\left(\mathrm{X}_{2}\right)$ terhadap variabel produktivitas kerja karyawan $(\mathrm{Y})$ dapat dilihat pada tabel 6 berikut ini: 
Tabel 6 Pengaruh Sistem Manajemen Keselamatan dan Kesehatan Kerja $\left(\mathrm{X}_{1}\right)$ dan Lingkungan Kerja $\left(\mathbf{X}_{2}\right)$ terhadap variabel Produktivitas Kerja Karyawan (Y)

\begin{tabular}{|c|c|c|c|c|c|}
\hline \multirow[t]{2}{*}{ Variabel } & \multirow{2}{*}{$\begin{array}{c}\text { Koefisien } \\
\text { Jalur }\end{array}$} & \multirow{2}{*}{$\begin{array}{l}\text { Pengaruh } \\
\text { Langsung }\end{array}$} & \multicolumn{2}{|c|}{$\begin{array}{c}\text { Pengaruh Tidak } \\
\text { Langsung }\end{array}$} & \multirow{2}{*}{$\begin{array}{l}\text { Subtotal } \\
\text { Pengaruh }\end{array}$} \\
\hline & & & $\mathrm{X1}$ & $\mathrm{X} 2$ & \\
\hline SMK3 & 0,597 & 0,356 & -------- & 0,068 & 0,424 \\
\hline Lingkungan Kerja & 0,226 & 0,051 & 0,068 & ------- & 0,119 \\
\hline \multicolumn{5}{|c|}{ Total Pengaruh } & 0,543 \\
\hline \multicolumn{5}{|c|}{ Pengaruh Variabel Lain } & 0,457 \\
\hline
\end{tabular}

Sumber: Hasil Pengolahan Data, 2019

Pada tabel 6 di atas menunjukkan bahwa total pengaruh yang disebabkan Sistem Manajemen Keselamatan dan Kesehatan Kerja $\left(\mathrm{X}_{1}\right)$ dan lingkungan kerja $\left(\mathrm{X}_{2}\right)$ terhadap variabel produktivitas kerja karyawan $(\mathrm{Y})$ yaitu sebesar 0,543 atau 54,3\% adapun pengaruh variabel lain diluar model adalah sebesar 0,457 atau $45,7 \%$.

Tabel 7 Koefisien Determinasi Model Summary

\begin{tabular}{|l|r|r|r|c|}
\hline Model & $\mathrm{R}$ & $\mathrm{R}$ Square & $\begin{array}{c}\text { Adjusted R } \\
\text { Square }\end{array}$ & $\begin{array}{c}\text { Std. Error of the } \\
\text { Estimate }\end{array}$ \\
\hline 1 &, $737^{\mathrm{a}}$ &, 543 &, 534 & 5,01682 \\
\hline
\end{tabular}

Sumber: Hasil Pengolahan Peneliti, 2019

Berdasarkan tabel 7 di atas menunjukan bahwa koefisien determinasi $\left(\mathrm{R}^{2}\right)$ sebesar 0,543 berarti 54,3\% variabel produktivitas kerja (Y) bisa diterangkan oleh variabel Sistem Manajemen Keselamatan dan Kesehatan Kerja $\left(\mathrm{X}_{1}\right)$ dan lingkungan kerja $\left(\mathrm{X}_{2}\right)$, atau dapat diartikan bahwa Sistem Manajemen Keselamatan dan Kesehatan Kerja $\left(\mathrm{X}_{1}\right)$ dan lingkungan kerja $\left(\mathrm{X}_{2}\right)$ memiliki konstribusi terhadap produktivitas kerja karyawan (Y) sebesar 54,3\% sedangkan sisanya 45,7\% merupakan kontribusi variabel lain $(\varepsilon)$ yang tidak diteliti.

\section{Hipotesisi Korelasi Antara Sistem Manajemen Keselamatan dan Kesehatan} Kerja $\left(\mathbf{X}_{1}\right)$ dan Lingkungan Kerja $\left(\mathbf{X}_{2}\right)$

Pengujian hipotesis hubungan antara Sistem Manajemen Keselamatan dan Kesehatan Kerja $\left(\mathrm{X}_{1}\right)$ dan Lingkungan Kerja $\left(\mathrm{X}_{2}\right)$ dilakukan dengan menggunakan uji statistic t, yaitu dengan rumus sebagai berikut (Riduwan, 2010).

$$
\mathrm{t}=\frac{r \sqrt{n-2}}{\sqrt{1-r^{2}}}
$$


Diketahui :

$\mathrm{r}=0,503$

$\mathrm{n}=102$

Maka :

$\mathrm{t}=\frac{0,503 \sqrt{102-2}}{\sqrt{1-0,503^{2}}}$

$\mathrm{t}=\frac{0,503(10)}{\sqrt{1-0,253}}$

$\mathrm{t}=\frac{5,03}{0,747}$

$\mathrm{t}=6,734$

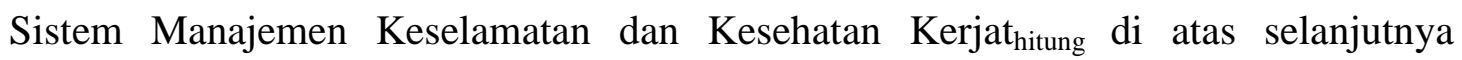
dibandingkan dengan $\mathrm{t}_{\text {tabel }}$ pada tingkat kesalahan $1 \%$, $\mathrm{db}=\mathrm{n}-2=102-2=100$, maka diperoleh $t_{\text {tabel }}=2,639$. Dengan demikian diketahui $t_{\text {hitung }}(6,734)>t_{\text {tabel }}(2,639)$, maka dapat dinyatakan bahwa $\mathrm{H}_{\mathrm{o}}$ ditolak, artinya ada hubungan yang signifikan antara Sistem Manajemen Keselamatan dan Kesehatan Kerja $\left(\mathrm{X}_{1}\right)$ dan Lingkungan Kerja $\left(\mathrm{X}_{2}\right)$.

\section{Hipotesis Pengaruh Variabel secara Parsial}

Pengaruh Sistem Manajemen Keselamatan dan Kesehatan Kerja secara parsial terhadap Produktivitas Kerja Karyawan dapat diketahui melalui pengujian statistik dengan menggunakan hipotesis sebagai berikut:

$\mathrm{H}_{0}$ : pyx $_{1}=0$ : Tidak terdapat pengaruh Sistem Manajemen Keselamatan dan Kesehatan Kerja terhadap Produktivitas Kerja Karyawan.

$\mathrm{H}_{1}: \operatorname{pyx}_{1} \neq 0$ : Terdapat pengaruh Sistem Manajemen Keselamatan dan Kesehatan Kerja terhadap Produktivitas Kerja Karyawan

Kriteria Uji : Tolak $\mathrm{H}_{\mathrm{o}}$ jika Sig. $<\alpha$ atau $\mathrm{t}_{\text {hitung }}>\mathrm{t}_{\text {tabel }}$

Untuk pengaruh Sistem Manajemen Keselamatan dan Kesehatan Kerjasecara parsial terhadap Produktivitas Kerja Karyawan dengan tingkat signifikan $(\alpha)=1 \%$, degree of freedom $(\mathrm{df})=(\mathrm{n}-2)=102-2=100$ diperoleh $\mathrm{t}_{\text {tabel }}=2,639$. Berdasarkan tabel 4.102 di atas, menunjukan bahwa $t_{\text {hitung }}=7,595$ dan sig. 0,000. Pengaruh $\mathrm{X}_{1}$ secara Parsial terhadap $\mathrm{Y}$ diperlihatkan pada tabel sebagai berikut: 
Tabel 8 Pengaruh ParsialSistem Manajemen Keselamatan dan Kesehatan Kerja $\left(X_{1}\right)$ terhadap Produktivitas Kerja Karyawan (Y)

\begin{tabular}{|c|c|c|c|c|c|}
\hline Structural & Sig. & $\mathbf{A}$ & $\mathbf{t}_{\text {hitung }}$ & $\mathbf{t}_{\text {tabel }}$ & Kesimpulan \\
\hline pyx $_{1}$ & 0,000 & 0,01 & 7,595 & 2,639 & $\mathrm{H}_{\mathrm{o}}$ ditolak \\
\hline
\end{tabular}

Sumber : Hasil Pengolahan Data, 2019

Tabel 8 di atas menunjukan bahwa nilai sig. $(0,000)>\alpha(0,01)$ dan $t_{\text {hitung }}(7,595)<$ $t_{\text {tabel }}(2,639)$ maka $\mathrm{H}_{\mathrm{o}}$ diterima. Dengan demikian dapat disimpulkan bahwa Sistem Manajemen Keselamatan dan Kesehatan Kerjasecara parsial berpengaruh terhadap Produktivitas Kerja Karyawan.

Pengaruh lingkungan kerja $\left(\mathrm{X}_{2}\right)$ terhadap produktivitas kerja karyawan $(\mathrm{Y})$ dapat diketahui melalui pengujian statistik dengan menggunakan hipotesis sebagai berikut :

$\mathrm{H}_{\mathrm{o}}$ : pyx $_{2}=0:$ Tidak terdapat pengaruh Lingkungan Kerja $\left(\mathrm{X}_{2}\right)$ terhadap Produktivitas Kerja Karyawan (Y)

$\mathrm{H}_{1}: \operatorname{pyx}_{2} \neq 0$ : Terdapat pengaruh Lingkungan Kerja $\left(\mathrm{X}_{2}\right)$ terhadap Produktivitas Kerja Karyawan (Y)

Kriteria Uji : Tolak $H_{o} j i k a$ Sig. $<\alpha$ atau $t_{\text {hitung }}>t_{\text {tabel }}$

Untuk pengaruh Lingkungan Kerja $\left(\mathrm{X}_{2}\right)$ terhadap Produktivitas Kerja Karyawan (Y) dengan tingkat signifikan $(\alpha)=1 \%$, degree of freedom $(\mathrm{df})=(\mathrm{n}-2)=102-2=100$ diperoleh $\mathrm{t}_{\text {tabel }}=2,639$. Berdasarkan tabel 4.102 di atas, menunjukan bahwa $\mathrm{t}_{\text {hitung }}=2,882$ dan sig. 0,000. Pengaruh $\mathrm{X}_{2}$ secara parsial terhadap $\mathrm{Y}$ diperlihatkan pada tabel sebagai berikut:

Tabel 9 Pengaruh Parsial Lingkungan Kerja $\left(\mathrm{X}_{2}\right)$ terhadap Produktivitas Kerja Karyawan $(Y)$

\begin{tabular}{|c|c|c|c|c|c|}
\hline Structural & Sig. & $\mathbf{A}$ & $\mathbf{t}_{\text {hitung }}$ & $\mathbf{T}_{\text {tabel }}$ & Kesimpulan \\
\hline Pyx $_{2}$ & 0,000 & 0,01 & 2,882 & 2,639 & $\mathrm{H}_{\mathrm{o}}$ ditolak \\
\hline
\end{tabular}

Sumber: Hasil Pengolahan Data, 2019

Tabel 9 diatas menunjukan bahwa nilai sig. $(0,000)<\alpha(0,01)$ dan $t_{\text {hitung }}(2,882)>t_{\text {tabel }}$ $(2,639)$ maka $\mathrm{H}_{\mathrm{o}}$ ditolak. Dengan demikian dapat disimpulkan bahwa Lingkungan Kerja $\left(\mathrm{X}_{2}\right)$ terhadap Produktivitas Kerja Karyawan (Y).

Pengaruh Ssitem Manajemen Keselamatan dan Kesehatan Kerja $\left(\mathrm{X}_{1}\right)$ dan Lingkungan Kerja $\left(\mathrm{X}_{2}\right)$ secara simultan (keseluruhan) terhadap Produktivitas Kerja Karyawan (Y) dapat diketahui melalui pengujian statistik dengan menggunakan hipotesis sebagai berikut :

$\mathrm{H}_{0}: \operatorname{pyx}_{1} \mathrm{x}_{2}=0 \quad$ : Tidak terdapat pengaruh Sistem Manajemen Keselamatan dan Kesehatan Kerjadan Lingkungan Kerja terhadap Produktivitas Kerja Karyawan. 
$\mathrm{H}_{1}: \operatorname{pyx}_{1} \mathrm{x}_{2} \neq 0 \quad$ : Terdapat pengaruh Sistem Manajemen Keselamatan dan Kesehatan Kerja $\left(\mathrm{X}_{1}\right)$ dan Lingkungan Kerja $\left(\mathrm{X}_{2}\right)$ terhadap Produktivitas Kerja Karyawan (Y)

Kriteria Uji : Tolak $H_{o}$ jika Sig. $<\alpha$ atau $t_{\text {hitung }}>f_{\text {tabel }}$

Untuk pengaruh Sistem Manajemen Keselamatan dan Kesehatan Kerja $\left(\mathrm{X}_{1}\right)$ dan Lingkungan Kerja $\left(\mathrm{X}_{2}\right)$ secara simultan (keseluruhan) terhadap Produktivitas Kerja Karyawan (Y) dengan tingkat signifikan $(\alpha)=1 \%$, degree of freedom $(\mathrm{df})=(\mathrm{n}-2)=102-2=100$, diperoleh $\mathrm{f}_{\text {tabel }}=3,09$. Sedangkan $\mathrm{f}_{\text {hitung }}$ dapat dilihat pada tabel di bawah ini :

Tabel 10 Hasil Perhitungan Nilai F ANOVA $^{\mathrm{b}}$

\begin{tabular}{|ll|r|r|r|r|r|}
\hline \multicolumn{1}{|l|}{ Model } & Sum of & & & & \\
& & Squares & df & Mean Square & F & Sig. \\
\hline 1 & Regression & 2964,456 & 2 & 1482,228 & 58,892 &, $000^{\text {a }}$ \\
& Residual & 2491,684 & 99 & 25,169 & & \\
& Total & 5456,141 & 101 & & & \\
\hline
\end{tabular}

a. Predictors: (Constant), Lingkungan Kerja, Sistem Manajemen Keselamatan dan Kesehatan Kerja

b. Dependent Variable: Produktivitas Kerja Karyawan

Sumber : Hasil Pengolahan Data, 2019

Berdasarkan tabel 10 di atas, menunjukan bahwa $\mathrm{f}_{\text {hitung }}=58,892$ dan sig. 0,000. pengaruh Sistem Manajemen Keselamatan dan KesehatanKerja (X1) dan Lingkungan Kerja (X2) secara simultan terhadap produktivitas kerja karyawan (Y) diperlihatkan pada tabel 11 di bawah ini:

Tabel 11 Pengaruh Simultan Sistem Manajemen Keselamatan dan Kesehatan Kerja (X1) dan Lingkungan Kerja (X2) terhadap Produktivitas Kerja Karyawan (Y)

\begin{tabular}{|c|c|c|c|c|c|}
\hline Structural & Sig. & A & F $_{\text {hitung }}$ & F $_{\text {tabel }}$ & Kesimpulan \\
\hline $\mathrm{Pyx}_{1} \mathrm{x}_{2}$ & 0,000 & 0,01 & 58,892 & 3,09 & $\mathrm{H}_{\mathrm{o}}$ ditolak \\
\hline
\end{tabular}

Sumber: Hasil Pengolahan Data, 2019

Tabel 11 di atas menunjukan bahwa nilai sig. $(0,000)<\alpha(0,01)$ dan $F_{h i t u n g}(58,892)>$ $F_{\text {tabel }}(3,09)$ maka $\mathrm{H}_{\mathrm{o}}$ ditolak. Dengan demikian dapat disimpulkan bahwa Sistem Manajemen Keselamatan dan Kesehatan Kerja (X1) dan lingkungan kerja (X2) secara simultan berpengaruh terhadap produktivitas kerja karyawan $(\mathrm{Y})$.

\section{KESIMPULAN}

Berdasarkan hasil penelitian dapat disimpulkan bahwa terdapat hubungan antara Sistem Manajemen Keselamatan dan Kesehatan Kerja $\left(\mathrm{X}_{1}\right)$ dengan Lingkungan Kerja $\left(\mathrm{X}_{2}\right)$ dengan nilai koefisien korelasi sebesar 0,503. Terdapat pengaruh secara parsial antara Sistem Manajemen Keselamatan dan Kesehatan Kerja dan lingkungan kerja terhadap produktivitas 
kerja karyawan, dimana Sistem Manajemen Keselamatan dan Kesehatan Kerja berpengaruh terhadap Produktivitas Kerja Karyawan secara positif sebesar 0,597 atau sebesar 59,7\%. Demikian juga dengan Lingkungan Kerja yang berpengaruh terhadap Produktiitas Kerja Karyawan sebesar 0,226 atau sebesar 22,6\%. Terdapat pengaruh secara simultan antara Sistem Manajemen Keselamatan dan Kesehatan Kerja dan lingkungan kerja terhadap produktivitas kerja karyawan dengan koefisien determinasi sebesar 0,543 atau sebsar 54,3\%, dan sedangkan sisanya 45,7 \% merupakan kontribusi variabel lain ( $(\varepsilon)$ yang tidak di teliti.

\section{DAFTAR PUSTAKA}

Aspiyah, M., \& Martono, S. (2016). Pengaruh Disiplin Kerja, Lingkungan Kerja dan Pelatihan pada Produktivitas Kerja. Management Analysis Journal, 5(4).

Bangun, W. (2012). Manajemen Sumber Daya Manusia. Bandung: Gelora Aksara Pratama.

Hasibuan, M. S. P. (2009). Manajemen Sumber Daya Manusia. Jakarta: Bumi Aksara.

Ike, R. (2008). Manajemen Sumber Daya Manusia. Yogyakarta: Andi Offset.

Kaswan. (2012). Manajemen Sumber Daya Manusia Untuk Keunggulan Bersaing Organisasi. Yogyakarta: Graha Ilmu.

Kurnia, A. (2005). Sistem Manajemen Keselamatan dan Kesehatan Kerja. Bekasi: STBA JIA

Lestari, T., \& Trisyulianti, E. (2009). Hubungan Keselamatan dan Kesehatan (K3) dengan Produktivitas Kerja Karyawan (Studi Kasus: Bagian Pengolahan PTPN VIII Gunung Mas, Bogor). Jurnal Manajemen, 1(1).

Mangkunegara, P. A. (2013). Manajemen Sumber Daya Manusia Perusahaan. Bandung: Remaja Rosdakarya.

Ramli, S. (2010). Sistem Manajemen Keselamatan dan Kesehatan Kerja OHSAS 18001. Jakarta: Dian Rakyat.

Ramli, S. (2013). Panduan Penerapan SMK3 yang Efektif. Jakarta: Dian Rakyat.

Ridley, J. (2006). Kesehatan dan Keselamatan Kerja. Jakarta: Erlangga.

Rinarti, D., \& Renyowijoyo, M. (2007). Pengaruh Ketidakpastian Lingkungan dan Budaya Organisasi Terhadap Partisipasi Penganggaran dan Kinerja Manajerial. Jurnal Bisnis dan Akuntansi, 9(2), 124-135.

Sakban, S., Nurmal, I., \& Ridwan, R. B. (2019). Manajemen Sumber Daya Manusia. Alignment: Journal of Administration and Educational Management, 2(1), 93-104.

Soehartono, I. (2000). Metode Penelitian Sosial. Jakarta: Remaja Rosdakarya.

Sugiyono. (2012). Metode Penelitian Kuantitatif Kualitatif dan R\&D. Bandung: Alfabeta

Sutanto, E. M., \& Suwondo, D. I. (2019). Hubungan Lingkungan Kerja, Disiplin Kerja, dan Kinerja Karyawan. Jurnal manajemen dan kewirausahaan, 17(2), 135-144. 